LINGUA, Vol. 16, No. 2, September 2019

p ISSN: 1979 9411; e ISSN: 2442 238X

Http://lingua.soloclcs.org; Email: presslingua@gmail.com

Center of Language and Cultural Studies, Surakarta, Indonesia

Kamarudin, Lalu; Syahdan \& Mahyudi, Johan. 2019. Kode Lakuan Perempuan

dalam Naskah Qurtubi Karya TGH. Alimuddin Praya Nusa Tenggara Barat.

Lingua (2019), 16(2): 247-270. Http://doi.org/10.30957/lingua.v16i2.271.

\title{
Kode Lakuan Perempuan dalam Naskah Qurtubi Karya TGH. Alimuddin Praya Nusa Tenggara Barat
}

\author{
Lalu Kamarudin, Syahdan \& Johan Mahyudi \\ Magister Pendidikan Bahasa Indonesia \\ Fakultas Keguruan dan Ilmu Pendidikan \\ Universitas Mataram \\ Jl. Majapahit No.62 Mataram, Nusa Tenggara Barat \\ E-mail: lalukamarudin16@gmail.com \\ Danavirha54@gmail.com \& mahyudi@unram.ac.id
}

\begin{abstract}
This study examines codes of conduct of women in carrying out their life according to the Qurtubi text by TGH. Alimuddin Praya West Nusa Tenggara. As the Islamic text from which values of women conducts based on hadits and the exemplars of Siti Fatimah, the daughter of the Muhammad Prophet, the text has been referenced as the core value of teaching for the society. This study used content analysis where themes and constructs of morale were focused from the text. The study used is a qualitative approach with descriptive analytical method, namely a method that expresses the actual situation in the text. Data were collected using documentation techniques, interviews and content analysis. The results show the code of conduct of women is conveyed through dialogue and actions experienced by the character depicted in the TGH Qurtubi text of Alimuddin Praya Lombok West Nusa Tenggara. The description of the action includes three codes, namely: 1) codes of conduct of women that depict social goodness, 2) codes of conduct of women that describe acts of conflict, and 3) codes of conduct of women that describe the attitude of guard and maintain. This teaching implies that codes of conduct of the women indicate the attitude to develop understanding, actions or the nature of maintaining positive norms that are not contrary to the values of religion, culture or customs that apply.
\end{abstract}

Keywords: Code, conduct, woman, Qurtubi text, work

\section{PENDAhULUAN}

Karya sastra pada hakekatnya merupakan suatu media yang mendayagunakan bahasa untuk mengungkapkan kehidupan manusia di dunia dan di akhirat. Sebuah karya sastra pada umumnya berisi tentang permasalahan yang melingkupi kehidupan manusia. Kemunculan sastra biasanya lahir atas dasar dorongan manusia untuk mengungkapkan eksistensi dirinya. Karya sastra juga berisi ungkapan-ungkapan yang "tidak bisa terungkap", maka penyair atau penulis menghasilkan kata-kata untuk 
LINGUA, Vol. 16, No. 2, September 2019

p ISSN: 1979 9411; e ISSN: 2442 238X

Http://lingua.soloclcs.org; Email: presslingua@gmail.com

Center of Language and Cultural Studies, Surakarta, Indonesia

Kamarudin, Lalu; Syahdan \& Mahyudi, Johan. 2019. Kode Lakuan Perempuan

dalam Naskah Qurtubi Karya TGH. Alimuddin Praya Nusa Tenggara Barat.

Lingua (2019), 16(2): 247-270. Http://doi.org/10.30957/lingua.v16i2.271.

memotret sebuah fakta aktual atau imajinatif yang tidak bisa digambarkan oleh orang lain. Ketika dijelaskan oleh sastrawan, maka fakta itu kemudian terlihat jelas oleh orang-orang awam atau pembaca.

Adapun salah satu di antara karya sastra tersebut adalah naskah. Naskah merupakan karya sastra yang menggunakan bahasa tulisan untuk menyampaikan berbagai informasi atau amanat yang tertuang di dalamnya. Naskah-naskah lama tersebut, dapat memberi sumbangan untuk studi tentang kelompok sosial budaya. Naskah-naskah tersebut merupakan dokumen yang mengandung pikiran, perasaan, dan pengetahuan dari suatu bangsa atau kelompok sosial budaya. Naskah merupakan salah satu sumber primer paling autentik yang dapat mendekatkan jarak antara masa lalu dan masa kini. Naskah menjanjikan jalan pintas yang istimewa (privileged shortcut access) untuk mengetahui khazanah intelektual dan sejarah sosial kehidupan masyarakat masa lalu, asalkan tahu cara membacanya dan menafsirkannya (Fathurrahman, 2015:27).

Naskah yang dimaksud di sini adalah naskah "Qurtubi". Naskah "Qurtubi" merupakan naskah yang ditulis oleh TGH. Alimuddin Praya Lombok Nusa Tenggara Barat. Naskah tersebut menggambarkan berbagai peristiwa yang berhubungan dengan kehidupan manusia di dunia maupun akhirat yang dikisahkan dalam bentuk pasal demi pasal dan disampaikan melalui dialog tokoh-tokoh atau pelaku. Secara khusus dalam Naskah Qurtubi tersebut dikisahkan tentang kehidupan perempuan/wanita. Kehidupan perempuan/wanita ini digambarkan sesuai dengan amal kebajikan atau keburukan yang telah dilakukan sewaktu di dunia. Apabila amal ibadahnya atau perbuatan yang dilakukan baik, maka ia akan mendapatkan balasan atau ganjaran yang sesuai dari Allah SWT., demikian sebaliknya.

Perempuan dalam Islam sangat dijunjung tinggi keberadaannya dari segi akhlak maupun moralnya. Citra baik yang melekat pada sosok wanita inilah yang akan menjadi cermin dalam kehidupan. Islam adalah agama yang berada di sisi Allah. Setiap muslim dituntut untuk taat terhadap ajaran yang sudah ditentukan oleh agama Islam yaitu menjadikan Al-quran dan hadist sebagai pedoman dalam menjalankan kehidupan. Sebagai agama yang rahmatan lil'alamin, Islam sanantiasa mengajak manusia kepada jalan Allah. Di dalam agama Islam telah diatur tentang cara berpakaian, bersikap, berakhlak, bergaul dan berkomunikasi yang baik. Islam lebih menekankan terhadap akhlak yang baik dalam berintraksi.

Berdasarkan uraian di atas, penelitian ini menfokuskan kajian pada naskah Qurtubi dengan rumusan masalah sebagai berikut:

1) Bagaimana kode lakuan perempuan yang berkaitan dengan tindakan kebajikan sosial?

2) Bagaimana kode lakuan perempuan yang berkaitan dengan pertentangan?

3) Bagaimana kode lakuan perempuan yang menggambarkan sikap menjaga atau memelihara? 


\section{LANDASAN TEORI}

\subsection{Kode Lakuan}

Kode lakuan atau aksi menurut Ratih (2016:3) merupakan perlengkapan utama teks. Setiap aksi atau tindakan dalam cerita dapat disusun atau disistematisasikan (codification). Dalam hal ini, tindakan adalah sintegmatik, berangkat dari titik yang satu ke titik yang lain. Tindakan-tindakan tersebut saling berhubungan walaupun sering tumpang tindih. Pada praktiknya, Barthes menerapkan juga prinsip penyeleksian, yaitu dengan mengenali gerak, aksi atau peristiwa. Vera (2014:30) menyatakan bahwa, kode lakuan (Proairetic Code ) merupakan tindakan naratif dasar (basic narrative action) yang tindakan-tindakannya dapat terjadi dalam berbagai peristiwa yang mungkin diindikasikan.

Menurut pandangan Umberto Eco (dalam Ratih, 2014:32) kode terdiri atas dua jenis yaitu: 1) kode berbentuk tunggal, dimana satu sistem unsur diterjemahkan dalam sistem lain. Misalnya kode morse, 2) kode memiliki konteks, maksudnya adalah kehidupan sosial dan kultural. Oleh karenannya, tanda memiliki banyak makna. Makna datang tergantung pada kemampuan pemakai bahasa atau sistem tanda. Selain pandangan tersebut di atas, Barthes mengklasifikasikan kode menjadi lima yaitu:

1. Kode aksi/tindakan/proairetik (proaretic code)

Kode aksi ini merupakan kode perlengkapan dalam suatu teks yang tersusun atau disistematisasikan (condification).

2. Kode teka-teki/hermeneutik (Hermeneutic code)

Kode ini berkisar pada tujuan atau harapan untuk mendapatkan "kebenaran" atas teka-teki (pernyataan) yang mungkin muncul di dalam teks.

3. Kode budaya (cultural code)

Kode budaya merupakan kode yang berkaitan dengan berbagai sistem pengetahuan atau sistem nilai yang tersirat di dalam teks, misalnya adanya bahasa atau kata-kata mutiara, benda-benda yang telah dikenal sebagai benda budaya.

4. Kode konotatif (connotatif code)

Kode ini merupakan kode yang berkenaan dengan tema-tema yang dapat disusun lewat proses pembacaan teks. Jika di dalam teks dijumpai konotasi kata, frasa, atau bahkan kalimat tertentu, semua itu dapat dikelompokkan ke dalam konotasi kata, frasa, atau kalimat yang mirip. Jika di dalam teks ditemukan sekelompok konotasi, berarti di dalamnya dapat ditemuan tema tertentu.

5. Kode sombolik (symbolic code)

Kode simbolik berkaitan dengan tema dala arti sebenarnya sehingga erat hubungaannya dengan kode konotatif, yaitu tema dalam keseluruhan teks cerita. (dalam Ratih, 2016:3-4).

Berdasarkan pemikiran tersebut, kode lakuan merupakan tindakan atau aksi yang digambarkan oleh seorang tokoh atau sekelompok orang dalam menjalankan peran kehidupan di dunia ini yang diaplikasikan oleh penulis dalam teks cerita. Aksi atau 
LINGUA, Vol. 16, No. 2, September 2019

p ISSN: 1979 9411; e ISSN: 2442 238X

Http://lingua.soloclcs.org; Email: presslingua@gmail.com

Center of Language and Cultural Studies, Surakarta, Indonesia

Kamarudin, Lalu; Syahdan \& Mahyudi, Johan. 2019. Kode Lakuan Perempuan

dalam Naskah Qurtubi Karya TGH. Alimuddin Praya Nusa Tenggara Barat.

Lingua (2019), 16(2): 247-270. Http://doi.org/10.30957/lingua.v16i2.271.

tindakan yang dilakukan oleh seseorang akan memiliki makna atau nilai tersendiri, yaitu ada yang bernilai positif dan negatif. Bila aksi atau tindakan seseorang baik maka dampaknya akan mendapatkan kebaikan pula, sebaliknya bila aksi atau lakuan seseorang jelek maka dampaknya juga kesengsaraan.

\subsection{Perempuan}

Perempuan merupakan salah satu diantara ciptaan Allah SWT. yang lemah lembut dan penuh kasih sayang karena perasaannya yang tulus. Secara umum sifat perempuan adalah keindahan, kelembutan, serta rendah hati dan memelihara. Perempuan yang dimaksud dalam penelitian ini yaitu perempuan-perempuan yang diceritakan di dalam naskah Qurtubi tersebut yang memiliki fisologis yang banyak dipengaruhi oleh struktur kebudayaan yang ada, khususnya oleh adat istiadat, sistem sosial-ekonomi, agama serta pengaruh pendidikan.

Dalam tinjauan etimologinya, kata perempuan bernilai cukup tinggi, tidak di bawah, tetapi sejajar, bahkan lebih tinggi daripada kata lelaki.

1) Secara etimologis, kata perempuan berasal dari kata empu yang berarti tuan, orang yang mahir/berkuasa, atau pun kepala, hulu, atau yang paling besar, maka kita kenal kata empu jari, ibu jari, empu gending :orang yang mahir menciptakan tembang.

2) Kata perempuan juga berhubungan dengan kata ampu:sokong, memerintah, penyangga, penjaga keselamatan.

3) Kata perempuan juga berakar erat dari kata empuan;kata ini mengalami pemendekan menjadi puan yang artinya sapaan hormat pada perempuan, sebagai pasangan kata tuan' sapaan hormat pada lelaki (Salih, 2001:4).

Berdasarkan uraian di atas, perempuan merupakan salah satu di antara ciptaan Allah SWT. yang mempuyai berbagai macam keistimewaan dibandingkan dengan pria, sehingga perempuan atau wanita menjadi sorotan utama dalam segala hal, bahkan agama Islam pun mendahulukan seorang wanita (ibu) daripada ayah.

\subsection{Naskah Qurtubi}

Naskah Qurtubi ini termasuk sastra kitab karena mencakup bidang yang sangat luas yang berisikan ajaran-ajaran agama. Karya sastra kitab dapat dijadikan rujukan mengenai Islam orang-orang yang sebagian besar kurang memahami bahasa Arab. Kebanyakan sastra kitab merupakan terjemahan atau hasil trasformasi karya-karya Arab. Bidang pengetahuan yang terdapat dalam karya sastra kitab ini adalah Ilmu Tauhid, fikih, hadist dan tasawuf (Fang, 1982). Naskah ini merupakan salah satu di antara manuskrip atau naskah kuno yang merupakan peninggalan nenek moyang yang ditulis pada kertas yang tulisannya sulit untuk dipahami.

Padanan kata naskah adalah al-makhtutat (Arab) yang didefinisikan sebagai: alkutub al-maktubah bil yad (buku yang dihasilkan melalui tulis tangan), manuscript (Inggris) yang antara lain didefinisikan sebagai: a book, document, or other composition written by hand (buku, dokumen, atau lainnya yang di tulis tangan) (Fathurrahman, 2015:22). 
LINGUA, Vol. 16, No. 2, September 2019

p ISSN: 1979 9411; e ISSN: 2442 238X

Http://lingua.soloclcs.org; Email: presslingua@gmail.com

Center of Language and Cultural Studies, Surakarta, Indonesia

Kamarudin, Lalu; Syahdan \& Mahyudi, Johan. 2019. Kode Lakuan Perempuan

dalam Naskah Qurtubi Karya TGH. Alimuddin Praya Nusa Tenggara Barat.

Lingua (2019), 16(2): 247-270. Http://doi.org/10.30957/lingua.v16i2.271.

Kata naskah atau manuskrip harus dibedakan dengan teks. Naskah adalah bentuk fisik dokumennya, sedangkan teks adalah tulisan atau kandungan isi yang terdapat di dalam naskah tersebut. Dalam konteks filologi Indonesia, kata "naskah" dan "manuskrip" dipakai dalam pengertian yang sama, yaitu merujuk pada dokumen yang di dalamnya terdapat teks tulisan tangan, baik berbahan kertas (kebanyakan kertas Eropa), daluwang (kertas lokal dari daun saeh), lontar (kertas lokal dari daun lontar), bambu dan lainnya (Fathurrahman, 2015:23).

Pada dasarnya, pengertian naskah tidak dibatasi oleh kandungan isinya, bisa berisi paparan teks dalam berbagai bidang yang sangat luas, angka matematis, peta, ilustrasi, gambar atau foto dan lain-lain. Sebuah naskah berilmunisasi bisa merupakan gabungan indah dari teks, gambar, hiasan pinggir, kaligrafi huruf atau ilustrasi sepenuh halaman (full page illustrations). Pada masa lalu sebelum ditemukan mesin cetak, semua dokumen dihasilkan melalui tulis tangan, baik berbentuk gulungan (scroll) papirus atau buku (codex) pada masa berikutnya (Fathurrahman, 2015:26).

Dalam tradisi tulis dan intelektual Arab-Islam, khususnya dalam teks-teks keagamaan, istilah teks dibedakan lagi menjadi tiga macam, yaitu (1) matan (matn), (2) komentar (syarh), dan (3) penjelasan (hasyiyah). Matan merupakan teks dasar utama dalam sebuah naskah yang menjadi landasan bagi seorang pengarang, bisa penulis matan itu sendiri atau orang lain, untuk menulis karya berupa syarh atau hasyiyah atasnya. Umumnya syarh atau hasyiyah ditulis karena pengarang merasa bahwa cakupan diskusi yang terdapat dalam matan dirasa terlalu ringkas dan tidak memadai, terutama bagi kelompok pembaca tertentu yang membutuhkan penjelasan lebih terperinci dan mendalam (Fathurrahman, 2015:28).

Pada hakekatnya, sastra lama/sastra lisan bisa dilihat dari dua bentuk, yaitu sastra lama lisan dan sastra lama tulis. Sastra lama lisan lebih awal muncul daripada sastra tulis. Sastra tulis ini muncul setelah dikenal sistem aksara di beberapa daerah di wilayah Indonesia. Karena itulah sering kali tatkala berbicara tentang sastra lama, maka pandangan kita langsung tertuju pada sastra lisan, yang merupakan titik awal berangkatnya konsep tentang pembahasan sastra lama.

Di dalam sastra lisan kaya dengan nilai-nilai budaya yang merupakan bagian dari kreativitas sastra. Sastra lisan merupakan terjemahan dari bahasa Inggris "oral literature", yang bermakna kesusastraan yang mencakup ekspresi kesastraan warga suatu kebudayaan yang penyampaiannya dan penyebarannya disebarkan dan diistrumenkan secara lisan (dari mulut ke mulut) Hutomo ( dalam Emzir dan Rohman, 2014:227). Berdasarkan uraian tersebut, Naskah Qurtubi adalah hasil interpretasi TGH. Alimuddin yang berbentuk karya sastra kitab yang diturunkan dari Al-Qur;an dan hadist, yang berisikan ajaran-ajaran Islam.

\section{METODE}

Penelitian ini menggunakan pendekatan kualitatif. Penelitian ini disesuaikan dengan masalah yang muncul dan tujuan penelitian yang ingin dicapai yaitu memperoleh gambaran tentang lakuan perempuan yang terdapat dalam naskah Qurtubi yang menjadi objek penelitian. Pendekatan kualitatif merupakan metode yang 
memanfaatkan cara-cara penafsiran dengan menyajikan secara deskriptif, memberikan perhatian utama pada makna dan pesan sesuai hakekat objek (Ratih, 2016:46-47). Penggunaan metode ini untuk membantu dan mempermudah upaya peneliti mengidentifikasi dan memaparkan unsur-unsur yang menjadi fokus penelitian.

Data penelitian ini bersumber dari data primer yaitu Naskah Qurtubi karya TGH. Alimudin Praya Lombok Nusa Tenggara Barat, dan data lain yang bersifat pustaka yang relevan dengan penelitian ini. Teknik pengumpulan data yang digunakan dalam penelitian ini yaitu:

1) Dokumentasi yaitu mencari data mengenai hal-hal yang berupa catatan, transkrip, buku, jurnal, majalah, surat kabar dan lainnya.

2) Pembacaan secara intensif dan aktif dengan mentode content analysis.

3) Wawancara yaitu teknik yang digunakan untuk menggali makna dan tanda yang berkaitan dengan naskah.

Setelah data tersebut terkumpul, maka dilakukan analisis data dengan mendeskripsikan tanda atau kode lakuan perempuan yang terdapat dalam naskah Qurtubi, sehingga pada akhirnya ditarik kesimpulan.

\section{HASIL DAN PEMBAHASAN}

Kode lakuan (Proaretic Code) merupakan kode yang menggambarkan suatu kelakuan atau tindakan yang dapat terjadi dalam berbagai peristiwa yang mungkin diindikasikan. Tindakan atau lakuan tersebut, saling berhubungan walaupun masih terjadi tumpang tindih. Berdasarkan teori Barthes tersebut, peneliti dapat mengklasifikasikan kode lakuan/tindakan perempuan dalam naskah Qurtubi menjadi tiga yaitu: (1) kode lakuan yang berhubungan dengan kebaikan sosial dan; (2) kode lakuan yang menggambarkan pertentangan dan; (3) kode lakuan yang menggambarkan sikap menjaga atau memelihara.

\subsection{Kode Lakuan Perempuan yang Menggambarkan Perilaku Kebaikan Sosial a. Perempuan yang menyusui anaknya...(hlm : 4).}

Kode lakuan perempuan yang menyusui anaknya merupakan kewajiban seorang ibu sebagaimana ditegaskan di dalam Alquran surat Al-Baqarah ayat: 233 yang artinya:

"Dan ibu-ibu hendaklah menyusui anak-anaknya selama dua tahun penuh, bagi yang ingin menyusui secara sempurna (QS.Al-Baqarah: 233)”.

Ayat tersebut, mencerminkan kewajiban seorang ibu untuk menyusui anaknya sampai dua tahun. Apabila seorang ibu yang memiliki anak tidak bersedia memberikan susuan atau menyusui anaknya dengan alasan untuk menjaga kecantikan, keseksian dan bentuk tubuhnya (termasuk payudaranya), maka di alam akhirat akan dicabik-cabik ular yang ganas sebagaimana sabda Rasulullah SAW berikut:

"Tiba-tiba aku melihat para wanita yang payudara mereka dicabik-cabik ular ganas. Aku bertanya, 'Kenapa mereka ?' Malaikat menjawab,'Mereka adalah 
LINGUA, Vol. 16, No. 2, September 2019

p ISSN: 1979 9411; e ISSN: 2442 238X

Http://lingua.soloclcs.org; Email: presslingua@gmail.com

Center of Language and Cultural Studies, Surakarta, Indonesia

Kamarudin, Lalu; Syahdan \& Mahyudi, Johan. 2019. Kode Lakuan Perempuan

dalam Naskah Qurtubi Karya TGH. Alimuddin Praya Nusa Tenggara Barat.

Lingua (2019), 16(2): 247-270. Http://doi.org/10.30957/lingua.v16i2.271.

para wanita yang tidak mau menyusui anak-anaknya (tanpa alasan syar'i)." (HR. Hakim). (dalam Khair, 2017:57).

Dalam naskah Qurtubi tergambar aksi kewajiban ibu/perempuan yang sedang menyusui anaknya berubah menjadi berubun-ubun. Terjadinya perubahan tersebut disebabkan oleh peristiwa yang sangat besar yaitu gempa, pertanda terjadinya kiamat, sebagaimana kutipan berikut:

"Dan bergerak-geraklah langit akan sebagian gerak yang amat keras dan gempalah bumi akan sebagian gempa yang amat keras seperti yang kena ombak yang besar hingga beranak bunting yang belum cukup bulannya, ada yang mati dalam perut ibunya. Dan lagi orang yang menyusui anaknya dan jadilah sekalian kanak-kanak itu berubun-ubun...”(hlm: 3 ).

Ganjaran pahala yang diperoleh oleh perempuan atau seorang ibu yang menyusui anaknya sesuai dengan tindakan yang dilakukan di antaranya sebagai berkut: Apabila seseorang perempuan mengandung janin dalam rahimnya, maka beristighfarlah para malaikat untuknya. Allah S.W.T. mencatatkan baginya setiap hari dengan 1,000 kebaikan dan menghapuskan darinya 1,000 kejahatan. Apabila seseorang perempuan mulai sakit hendak bersalin, maka Allah S.W.T. mencatatkan baginya pahala orang yang berjihad pada jalan-Nya. Apabila seseorang perempuan melahirkan anak, keluarlah dia daripada dosa-dosa seperti keadaan ibunya melahirkannya. Apabila telah lahir (anak) lalu disusui, maka bagi ibu itu setiap satu tegukan daripada susunya diberi satu kebajikan. Apabila semalaman (ibu) tidak tidur dan memelihara anaknya yang sakit, maka Allah S.W.T. memberinya pahala seperti memerdekakan 70 orang hamba dengan ikhlas untuk membela agama Allah S.W.T. Wanita yang memberi minum susu kepada anaknya daripada badannya (ASI) akan dapat satu pahala dari pada tiap-tiap tetes susu yang diberikannya (Dwiyanti, 2016:48-49).

Berdasarkan uraian di atas, tindakan seorang ibu yang menyusui anaknya merupakan kewajiban sosial yang sangat mulia dan harus dipertahankan oleh ibu-ibu, jangan sampai tidak memperhatikan hak anak untuk mendapatkan ASI, disebabkan oleh tindakan atau alasan yang bertentangan dengan ajaran agama, sehingga anak menjadi korban.

\section{b. Bangunlah Siti Fatimah dari kubrnya...(hlm : 54).}

Seluruh umat manusia sejak umat Nabi Adam sampai umat nabi akhir zaman yaitu umat baginda Rasulullah SAW.akan mengalami hari kebangkitan. Tujuan dibangkitkannya manusia adalah untuk diperlihatkan keadaan mereka (balasan) amal ibadahnya selama hidup di dunia. Semua manusia akan dibangkitkan dari dalam kuburnya menuju padang Mahsyar. Allah SWT. berfirman dalam Alquran yang artinya:

"Apabila bumi digoncangkan dengan goncangan (yang dahsyat),- Dan bumi telah mengeluarkan beban-beban yang berat (yang dikandung)nya, -Dan 
manusia bertanya :"Mengapa bumi (menjadi begini)?",-Pada hari itu bumi menceritakan beritanya,- Karena sesungguhnya Tuhanmu telah memerintahkan (yang demikian itu) kepadanya. Pada hari itu manusia keluar dari kuburnya dalam keadaan bermacam-macam, supaya diperlihatkan kepada mereka (balasan) pekerjaan mereka (QS Az-Zalzalah: 1-6)

TGH. Alimudin dalam karyanya menggambarkan bahwa aksi bangunnya Siti Fatimah terjadi pada saat anak-anak mencari ibunya, sebagaimana kutipan berikut:

"Maka datanglah sekalian kanak-kanak itu mengiringkan Malaikat Jibrail kepada Rasulullah SAW., maka menangislah Rasulullah SAW. serta kanakkanak dan Jibrail pun menangis sertanya. Kemudian bertanya kanak-kanak itu kepada Rasulullah SAW. dengan katanya, "Hai Rasulullah SAW. dimanakah tempat ibu kami, " maka sabda Rasulullah SAW." Hai kanak-kanak ibu engkau masih tinggal dengan Siti Fatimah daripada kuburnya". Maka memohon izin kanak-kanak itu sekalian pada Rasulullah SAW. akan mencari ibunya daripada kuburnya, maka disuruh oleh Rasulullah SAW. sekalian kanak-kanak itu pergi pada kubur ibunya, maka terbanglah sekalian kanak-kanak antara langit dan bumi dan membawa kendi yang berisi air kausar. Maka tatkala hendak datang pada kubur ibunya, maka datanglah sekaliannya pada bendera Siti Fatimah yang telah berdiri tempat masuk ummat Nabi Muhammad SAW. yang perempuan. Maka bangunlah Siti Fatimah daripada kuburnya dan memandang Siti Fatimah ke kanan dan ke kiri tiada seorang perempuan bangun daripada kuburnya.." (hlm:54).

Data tersebut mencerminkan aksi sosial Siti Fatimah terhadap anak-anak yang mencari ibunya, dan mengajak anak-anak tersebut kepada Rasulullah untuk menanyakan tempat ibunya.

\section{c. Pergilah Siti Fatimah menghadap Rasulullah SAW. ...(54-55)}

Peristiwa selanjutnya, yaitu Siti Fatimah menghadap Rasulullah SAW. untuk meyampaikan dan menanyakan umat Rasulullah SAW. yang perempuan sebagaimana kutipan:

"Maka pergilah Siti Fatimah menghadap kepada Ayahandanya Rasulullah SAW. dan menunggang buroknya. Maka datanglah Siti Fatimah ke hadapan baginda Rasulullah Saw., maka menilik Rasulullah SAW. serta bertanya pada Siti Fatimah dengan sabdanya, "Hai anakku Siti Fatimah dimanakah tempat umatku yang perempuan". Maka sahut Siti Fatimah, " adalah umat junjuanganku yang perempuan itu masih tinggal belum bangun daripada kuburnya"...(hlm:54-55) 
LINGUA, Vol. 16, No. 2, September 2019

p ISSN: 1979 9411; e ISSN: 2442 238X

Http://lingua.soloclcs.org; Email: presslingua@gmail.com

Center of Language and Cultural Studies, Surakarta, Indonesia

Kamarudin, Lalu; Syahdan \& Mahyudi, Johan. 2019. Kode Lakuan Perempuan

dalam Naskah Qurtubi Karya TGH. Alimuddin Praya Nusa Tenggara Barat.

Lingua (2019), 16(2): 247-270. Http://doi.org/10.30957/lingua.v16i2.271.

Kutipan tersebut, menggambarkan kode akhlak sosial, kebaktian, dan kepedulian Siti Fatimah terhadap umat Rasulullah SAW. yang perempuan, sehingga patut untuk diteladani oleh kaum perempuan sepanjang zaman dimana pun dan dijamin masuk surga, sebagaimana sabda Rasulullah SAW berikut:

Dari Anas r.a., Rasulullah SAW. bersabda, "Cukuplah bagimu sebagai tauladan dari wanita dunia, yaitu Marya binti Imran, Asiyah istri Fir'aun, Khadijah binti Khuwailid, dan Fatimah binti Muhammad." (HR. Tirmidzi) (dalam Afgandi,2017:131).

Hendaknya perempuan selalu berusaha meneladani wanita dunia tersebut, karena wanita-wanita itu merupakan wanita penghuni surga.

Kebaktian kepada kedua orang tua tercurah indahnya kasih sayang timbal balik antara anak dan orang tua. Kesuksesan dan kemuliaan hidup seorang anak pun sangat tergantung kepada kebaktian mereka kepada kedua orang tuanya. Bahkan, ridanya Allah SWT. saja, tergantung atas ridanya kedua orang tua kepada kita sebagai anaknya.

Perintah kebaktian terhadap orang tua selalu disandingkan dengan perintah untuk beribadah kepada Allah. Perintah berbakti kepada orang tua adalah salah satu perintah yang bersifat universal, yakni berlaku untuk seluruh umat manusia pada semua zaman. Allah SWT. berfirman dalam surat Al-Isra':23 artinya:

"Dan Tuhanmu telah memerintahkan supaya kamu jangan menyembah selai Dia dan hendaklah kamu berbuat baik kepada ibu bapakmu dengan sebaikbaiknya. Jika salah seorang di antara keduanya atau kedua-duanya sudah berumur lanjut dalam pemeliharaanmu, maka sekali-kali janganlah mengatakan kepada keduanya perkataan "ah" dan janganlah kamu membentak mereka dan ucapkanlah kepada merka ucapan yang mulia." Dan rendahkanlah dirimu terhadap mereka berdua dengan penuh keesayngan dan ucapkanlah :"Wahai Tuhanku, kasihilah mereka keduanya, sebagaimana mereka telah mendidik aku sewaktu kecil”, (QS.Al-Isra': 23).

Ayat ini menggambarkan cara kita berbakti kepada kedua orang tua. Kita sebagai anak jangan sampai menyakiti keduanya. Kita hanya mengatakan "ah" saja sudah termasuk ucapan yang mengandung dosa, apalagi tindakan atau perkataan lainya yang menyebabkan orang tua menjadi tersinggung, pasti kita mendapatkan dosa besar.

\section{d. Perempuan yang tiada durhaka pada suaminya...(hlm:56)}

Perempuan yang tiada durhaka kepada suaminya atau seorang istri yang selalu berbakti kepada suaminya adalah ciri penghuni surga. Hal ini sejalan dengan sabda Rasulullah SAW:

Artinya."Jika seorang wanita mengerjakan shalat 5 waktu, berpuasa di bulan Ramadhan, menjaga kemaluannya, menaati suaminya, niscaya akan dikatakan kepadanya, masuklah ke surga.”(HR.Ahmad) (dalam Afgandi,2017:153).

Allah SWT. mensifati wanita shalehah melalui firmanNya: 
"Maka perempuan-perempuan yang shaleh adalah mereka yang taat (kepada Allah) dan menjaga diri ketika (suaminya) tidak ada karena Allah telah menjaga (mereka)...”(QS.An-Nisaa:34).

TGH. Alimuddin dalam naskah Qurtibi, menggambarkan bahwa istri atau perempuan yang taat kepada suaminya berada di bawah naungan bendera Siti Fatimah dan diberikan pakaian yang bernama sibabun sundusi wastabraki, sebagaimana kutipan berikut:

"Maka sabda Rasulullah SAW., "Hai anakku Siti Fatimah panggil olehmu tatkala sampai ke kuburnya dan beri olehmu pakaian yang bernama sibaabun sundusi wastabroki akan pekakas perempuan yang tiada durhaka pada suaminya dan suruh masuk di bawah benderamu...(hlm :56)

Data di atas, mencerminkan kode lakuan perempuan yang tidak durhaka kepada suami, kode ini mengambarkan aksi sosial yang harus dipertahankan oleh perempuan atau seorang istri.

Berdasarkan ayat dan hadist tersebut, perempuan atau seorang istri yang selalu taat menjalankan perintah Allah SWT. dan berbakti kepada suaminya dalam hal kebaikan, maka ia akan mendapatkan tempat di surga.

\section{e. Perempuan yang suka dipermadu...(hlm:56)}

Perempuan yang suka, ikhlas dan rida, apabila suaminya berpoligami merupakan tindakan atau sikap yang sangat mulia dan akan mendapatkan ganjaran pahala dari Allah SWT. karena ketaatannya pada suaminya.

Rasulullah SAW. menjeskan, perempuan yang taat kepada Allah dalam menjalankan perintahNya, taat, ihklas, dan rida terhadap suaminya dengan sikap yang baik maka perempuan tersebut dipersilahkan memasuki surga, sebagaimana hadist berikut:

"Jika seorang istri mengerjakan shalat 5 waktu, berpuasa di bulan Ramadhan, menjaga kemaluannya, menaati suami, niscaya akan dikatakan kepadanya,"masuklah ke surga," (HR. Ahmad) (dalam Afgandi, 2017:59).

Di dalam naskah Qurtubi, TGH. Alimuddin mengungkapkan bahwa perempuan yang suka, ihklas, dan rida dipoligami, maka ia akan mendapatkan naungan di bawah bendera Siti Fatimah, sebagaimana kutipan berikut:

"Kemudian panggil olehmu perempuan yang suka dipermadu/diperduakan, panggil olehmu sekalian perempuan yang mati lakinya yang redho ia dan panggil olehmu perempuan yang bakti pada dua ibu bapaknya dan panggil olehmu perempuan yang tiada pernah berkawin di dalam dunia yang redha, 
maka suruh masuk di bawah benderamu supaya jangan dimakan oleh neraka itu..."(hlm:56).

Berdasarkan penjelasan hadist tersebut, tergambar keberuntungan bagi orangorang yang selalu taat, ikhlas dan rida atas ketentuan dan perintah Allah SWT. dalam menjalankan kehidupan di dunia.

\section{f. Perempuan yang bakti pada dua ibu bapaknya....(hlm:56).}

Islam sebagai suatu agama tidak hanya mengajarkan kepada umatnya untuk berbuat baik kepada Allah dan taat pada aturan-aturan yang diperintahkan melalui Rasulullah. Selain itu, mengajarkan umatnya untuk berbuat baik kepada sesama manusia, terutama terhadap kedua orang tua, sebagaimana firman Allah dalam surat AnNisaa ayat 36 yang artinya:

"Sembahlah Allah dan janganlah kamu mempersekutukanNya dengan sesuatu pun. Dan berbuat baiklah kepada kedua orang tua, karib-kerabat, anak-anak yatim,orang-orang miskin, tetangga yang dekat dan tetangga yang jauh, teman sejawat, ibnu sabil dan hamba sahayamu. Sesungguhnya Allah tidak menyukai orang-orang yang sombong dan membagga-banggakan diri.”(QS.An-Nisaa:36).

TGH. Alimuddin menggambarkan di dalam naskah Qurtubi bahwa, perempuan yang berbakti kepada kedua ibu bapaknya berada di bawah bendera Siti Fatimah dan masuk surga bersama perempuan-perempuan yang berbuat taat di dunia, sebagaimana kutipan berikut:

"Maka sabda Rasulullah SAW., "Hai anakku Siti Fatimah panggil olehmu tatkala sampai ke kuburnya dan beri olehmu pakaian yang bernama sibaabun sundusi wastabroki akan pakaian perempuan yang tiada durhaka pada suaminya dan suruh masuk di bawah benderamu dan anak-anak mati kecil sebelum baliq. Kemudian panggil olehmu perempuan yang suka dipermadu/diperduakan, panggil olehmu sekalian perempuan yang mati lakinya yang rida dan panggil olehmu perempuan yang bakti pada dua ibu bapaknya dan panggil olehmu perempuan yang tiada pernah berkawin di dalam dunia yang rida, maka suruh masuk di bawah benderamu supaya jangan dimakan oleh neraka itu..(hlm:56)

Kode lakuan perempuan yang berbakti kepada kedua ibu bapaknya merupakan perbuatan yang sangat mulia dan hukumnya wajib, karena kedua orang tualah yang menyebabkan kita semua lahir ke dunia fana dengan taruhan jiwa dan raga, serta yang telah mendidik dan membesarkan kita sejak kecil hingga dewasa. Rasulullah SAW. bersabda yang artinya: 
"Barang siapa yang berbuat rida kepada kedua orang tuanya, maka berarti dia rida kepada Allah. Dan barangsiapa berbuat durhaka kepada kedua orang tuanya, maka sesungguhnya ia berbuat durhaka kepada Allah."

Hadist tersebut mencerminkan sikap seseorang kepada kedua orang tua. Apabila seorang berbakti kepada kedua orang tuanya berarti dia telah berbakti dan taat kepada Allah SWT. sebaliknya apabila seorang anak durhaka kepada kedua orang tuanya berarti dia juga durhaka kepada Allah SWT.

\section{g. Menyahutlah perempuan yang bakti pada lakinya...(hlm : 58).}

Dalam naskah Qurtubi terungkap dialaog antara perempuan yang berbakti dengan perempuan yang durhaka, Sebagaimana kutipan berikut ini:

"Hai perempuan yang di bawah bendera Siti Fatimah tolonglah aku daripada kesusahan aku ini karena amat sakit dan pecah kepalaku dan digigit aku oleh anjing dan kera, " maka sahut perempuan yang bakti pada lakinya dan yang rida diperduakan akan dia dengan katanya, "tiada kuasa menolong akan kamu pada ini hari, karena Allah Ta'aala sangat murkakan kamu”....(hlm : 58).

TGH. Alimuddin menggambarkan kode lakuan/aksi perempuan yang berbakti dan taat itu kepada Allah SWT. dengan perempuan yang durhaka. Perempuan yang durhaka itu meminta bantu kepada perempuan yang taat atas kepedihan yang dialaminya, namun perempuan yang taat itu menjawab bahwa dia tidak bisa memberikan bantuan, karena Allah sangatlah murka kepada perempuan yang durhaka itu. Lakuan/aksi perempuan yang baik tersebut merupakan kode lakuan/aksi sosial, karena masih merasa kasihan dan berkeinginan untuk membantu, akan tetapi tidak berdaya.

\subsection{Kode Lakuan Perempuan yang Menggambarkan Perilaku Pertentangan a. Perempuan yang durhaka pada suaminya....(hlm:57).}

Perempuan yang durhaka pada suaminya merupakan perilaku yang bertentangan dengan ajaran agama, sehingga Allah SWT. memberikan balasan dan tempat yaitu neraka. Dalam sebuah hadist Rasulullah SAW. bersabda:

"Aku lihat api neraka, tidak pernah aku melihatnya seperti hari ini, karena ada pemandangan yang dahsyat di dalamnya.Telah aku saksikan kebanyakan ahli neraka ialah wanita, Rasulullah ditanya, "mengapa demikian ya Rasulullah ?'Baginda menjawab, "wanita yang mengkufurkan suaminya dan mengkufurkan ihsannya. Jikalau engkau berbuat baik kepadanya seberapa banyak pun dia masih belum merasa berpuas hati dan merasa cukup " (HR. Al-Buhari).

Dalam hadist lain Rasulullah SAW. bersabda: 
"kebanyakan ahli neraka adalah terdiri daripada kaum wanita, "maka menangislah mereka dan bertanya dari salah seorang di antara mereka, 'mengapa terjadi demikian, adalah karena mereka berzina atau membunuh anak atau kafir ? "Beginda menjawab "Tidak, mereka ini ialah mereka yang mengucapkan lidah menyakiti suami dan tidak bersyukur akan nikmat yang disediakan oleh suaminya"(HR. Muslim).

"Dari Amr bin Al-Haris bin Al-Musthaliq, ia berkata, 'Dikatakan bahwa manusia yang paling berat siksanya adalah dua orang, yaitu wanita yang durhaka kepada suaminya dan imam suatu kaum tapi mereka membencinya, "(HR. Tirmidzi) (dalam Khair, 2017:67).

TGH.Alimuddin mencerminkan balasan bagi perempuan yang durhaka pada suaminya sebagai berikut:

“...Firman Tuhan bagi malaikat Zabaniyah dengan firmanNya "Hai Zabaniyah pergi engkau ke neraka, ambil olehmu rantai yang merah dan kera dan anjing daripada api neraka, bawa olehmu pada perempuan yang durhaka pada lakinya,..Maka takala bangun perempuan yang durhaka itu, maka dipukul oleh malaikat Zabaniyah dengan pemukul dari api nerka yang sangat panas serta digigit oleh anjing dan ular...(hlm:57).

Berdasarkan kutipan naskah dan hadist tersebut, digambarkan tentang siksaan bagi perempuan atau istri yang tidak taat terhadap perintah Allah dan tidak mau berbakti kepada suaminya, maka dia mendapatkan tempat yaitu neraka. Perempuan tersebut disiksa, dipukul, dirantai, digigit anjing dan ular. Oleh karena itu, bagi perempuan yang bersuami supaya meningkatkan ketaqwaannya kepada Allah SWT. dengan mengikuti segala perintahNya dan manjauhi laranganNya, dan memelihara hubungan baik dengan suaminya dengan mengikuti perintahnya dalam kebajikan dan kebenaran. Apabila hal tersebut dijalankan dengan tulus ikhlas dan rida, maka dapat digolongkan bahwa perempuan tersebut termasuk perempuan atau istri yang shalehah dan merupakan salah satu di antara calon penghuni surga.

\section{b. Perempuan yang durhaka kepada kedua orang tuanya...(hlm:57).}

Perempuan yang durhaka kepada kedua orang tuanya adalah sikap yang bertentangan dengan ajaran agama. Dalam ajaran agama Islam mewajibkan kita berbakti kepada kedua orang tua. Hal tersebut, sesuai dengan firman Allah SWT. yang artinya:

"kami perintahkan kepada manusia supaya berbuat baik kepada kedua orang ibu bapaknya, ibunya mengandung dengan susah payah, dan melahirkannya 
dengan susah payah (pula), masa mengandung sampai menyapihnya adalah tiga puluh bulan, (QS. Al-Ahqaf :15) (dalam Hidayatulloh, 2013:504).

Perbuatan durhaka kepada kedua orang tuanya juga merupakan perbuatan dosa besar sebagaimana sabda Rasulullah SAW. dalam sebuah hadist yang diriwayatkan oleh Imam Buhari dan Imam Muslim dari Abi Bakrah:

Artinya: "Maukah aku tunjukkan kepadamu tentang dosa yang paling besar ? "Nabi bersabda sampai tiga kali. Sahabat menjawab. "Mau ya Rasulullah, "Nabi bersabda : "Ialah menyekutukan Allah dan menyakiti kepada kedua orang tua”.(HR. Buhari dan Muslim).

TGH. Alimuddin di dalam naskah Qurtubi menjelaskan balasan yang akan diterima oleh orang yang tidak berbuat baik kepada kedua orang tuanya, sebagaimana kutipan ini:

"Kemudian firman Tuhan bagi Malaikat Zabaniyah dengan firmanNya, "Hai Zabaniyah pergi engkau ke neraka ambil olehmu rantai yang merah dan kera dan anjing daripada api neraka bawa olehmu pada perempuan yang durhaka pada lakinya dan tiada bakti pada ibu bapaknya dan pada perempuan yang tiada suka diperduakan oleh suaminya". Maka pergi Malaikat Zabaniyah dengan membawa yang tersebut itu. Maka tatkala bangun perempuan itu daripada kuburnya perempuan yang durhaka itu, maka dipukul oleh Malaikat Zabaniyah dengan pemukul dari api neraka yang sangat panas serta digigit oleh anjing dan kera..."(hlm :57).

Lakuan/aksi perempuan atau siapa saja yang durhaka terhadap kedua orang tuanya merupakan sikap yang bertentangan dengan agama maupun adat dan budaya kita. Oleh karena itu, kita harus menjaga dan memelihara mereka.

\section{c. Perempuan yang tiada suka diperduakan....(hlm:57).}

Dalam naskah tersebut, pengarang mengungkapkan tentang perempuan yang tidak suka dimadu, artinya seorang perempuan tidak rida atau ikhlas melihat suaminya kawin lagi dengan perempuan lain. Gambaran ini merupakan sikap atau tindakan seorang perempuan yang kurang baik. Perempuan yang rida dan ikhlas terhadap suaminya poligami akan mendapatkan tempat yang baik di bawah bendera Siti Fatimah, namun sebaliknya perempuan yang tidak rida dan ikhlas akan mendapatkan balasan, sebagaimana kutipan berikut:

“..Maka tatkala bangun perempuan yang durhaka itu, maka dipukul oleh malaikat Zabaniyah dengan pemukul dari api neraka yang sangat panas serta digigit oleh anjing dan ular.”..(hlm:57). 
LINGUA, Vol. 16, No. 2, September 2019

p ISSN: 1979 9411; e ISSN: 2442 238X

Http://lingua.soloclcs.org; Email: presslingua@gmail.com

Center of Language and Cultural Studies, Surakarta, Indonesia

Kamarudin, Lalu; Syahdan \& Mahyudi, Johan. 2019. Kode Lakuan Perempuan

dalam Naskah Qurtubi Karya TGH. Alimuddin Praya Nusa Tenggara Barat.

Lingua (2019), 16(2): 247-270. Http://doi.org/10.30957/lingua.v16i2.271.

Data tersebut mencerminkan balasan bagi perempuan yang durhaka yaitu perempuan yang tidak ikhlas, tidak suka dan tidak rida melihat suaminya poligami. Sebaiknya, seorang perempuan yang suaminya berpoligami bersikap menerima dengan hati yang tulus dan mengembalikan persoalan tersebut kepada ketentuan Allah SWT.

\section{d. Perempuan nusyuz pada lakinya....(hlm:62).}

Kata nusyus menurut kamus bahasa Indonesia adalah perbuatan tidak taat dan membangkangnya seorang istri terhadap suaminya (tanpa alasan) yang tidak dibenarkan oleh hukum. Sedangkan menurut istilah kata nusyus adalah pelanggaran yang dilakukan oleh seorang istri terhadap kewajibannya yang ditetapkan oleh Allah SWT. agar taat kepada suaminya, sehingga istri seolah-olah menempatkan dirinya lebih tinggi daripada suaminya padahal menurut biasanya dia mengikuti atau mematuhi suaminya itu.

Apabila seorang istri menentang kehendak suami dengan tidak ada alasan yang dapat diterima menurut hukum syara', tindakan itu dipandang durhaka. Apabila hal itu terjadi, seorang suami wajib memberikan nasihat dengan sebaik-baiknya. Apabila hal tersebut, sudah dilakukan belum juga terjadi perubahan, maka hendaklah suami berpisah tidur dengan istri. Kalau masih meneruskan kedurhakaanya, maka diperbolehkan memukulnya, tetapi jangan sampai merusak badannya. Firman Allah SWT:

"Wanita-wanita yang kamu khawatir nusyusnya, maka nasihatilah mereka, dan pisahkan diri dari tempat tidur mereka, dan pukullah mereka.”(An-Nisaa':34).

TGH. Alimuddin mendefinisikan perempuan yang nusyus sebagaimana kutipan berikut:

"Adapun artinya nusyus seperti berkata lakinya pada istrinya,"Hai istriku aku berkehendak pergi sekarang pada rumah si anu, karena aku ada hajat, tiba-tiba lain rupanya dan masam mukanya atau keras suaranya, padahal sebelum lakinya menyatakan dirinya hendak pergi ke rumah si anu lemah lembut mukanya dan suaranya manis, atau terus masuk ke dalam rumahnya menutup pintunya. Maka tatkala datang suaminya dari perginya itu, maka memintakan membukakan pintu rumahnya, maka hingga ia sampai tiga kali baru membukakan pintu rumahnya dan hingga marah dan masuk lakinya ke dalam rumahnya atau berpindah tempat tidurnya atau keluar dari rumahnya dengan tiada izin lakinya atau disuruh lakinya tiba-tiba masam mukanya karena sakit hatinya atau tatkala dipanggil oleh lakinya tiada lekas menjawab sehingga tiga kali, atau disuruh oleh lakinya tiada lekas bangun....(hlm :62-63).

Adapun balasan yang di terima oleh perempuan yang nusyus, di dalam naskah Qurtubi digambarkan sebagai berikut:

"Maka tatkala bangkit daripada kuburnya sekalian perempuan yang nusyuz itu, tiba-tiba hidungnya berat, lagi memncoba pegang hidungnya tiba-tiba didapatnya hidungnya besar dan panjang kira-kira empat puluh hasta lagi hitam 
LINGUA, Vol. 16, No. 2, September 2019

p ISSN: 1979 9411; e ISSN: 2442 238X

Http://lingua.soloclcs.org; Email: presslingua@gmail.com

Center of Language and Cultural Studies, Surakarta, Indonesia

Kamarudin, Lalu; Syahdan \& Mahyudi, Johan. 2019. Kode Lakuan Perempuan

dalam Naskah Qurtubi Karya TGH. Alimuddin Praya Nusa Tenggara Barat.

Lingua (2019), 16(2): 247-270. Http://doi.org/10.30957/lingua.v16i2.271.

sebagai arang. Maka terkejutlah hingga berteriak dengan katanya," Hai lakiku tolonglah aku pada ini hari, karena hidungku terlalu panjang lagi hitam," maka menangislah ia dan berhimpunlah lalat, sahuk serta ular pada hidungnya. Maka memegang telinganya tiba-tiba terdapat terlalu besar dan panjangnya kira-kira empat puluh hasta dan lebarnya demikian jua. Maka semankin terkejut dan berteriak-teriak dengan sehabis-habis katanya," Hai lakiku janganlah buang aku pada ini hari serta menangis ia sebab susahnya barangkali tiada diakui oleh suaminya. Maka keluarlah lidahnya sampai ke tanah, maka berhimpunlah ular dan lalat dan kala pada lidahnya..”(hlm:62-63).

Data tersebut mencermintakan kode lakuan perempuan yang nusyus pada suaminya. Oleh karena itu, seyogyanya seorang istri atau perempuan yang bersuami berusaha mentaati, mengindahkan perintah suami dalam kebaikan dan kebenaran, serta tidak menyinggung perasaanya, sehingga di akhirat akan mendapatkan tempat yang baik disisiNya.

\section{e. Perempuan yang minta talak pada lakinya...(hlm :80).}

Kata "talak" memiliki makna perceraian antara suami dan istri. Talak merupakan perbuatan yang halal, namun juga suatu perbuatan yang dibenci oleh Allah. TGH. Alimuddin menggambarkan balasan terhadap perempuan yang minta talak kepada suaminya, sebagaimana kutipan berikut:

"Ini suatu pasal pada menyatakan perempuan yang minta talak pada lakinya. Adapun kemudian daripada yang tersebut itu, maka adalah cerita ketika bangkit sekalian perempuan yang minta talak pada lakinya, maka ditalak oleh lakinya, sebab panas hati lakinya dimintai talak itu. Maka tatkala bangkit perempuan yang minta talak daripada kuburnya, maka hitam rupa badanya dan keluar lidahnya sampai ke tanah dan ekornya keluar sampai empat puluh hasta panjangnya dan bangkitnya itu bertelanjang dan didapatnya dua parji, yang satunya di muka dan satu di belakang. Maka terkejutlah perempuan itu melihat rupanya, sehingga ia berteriak.

Data di atas, mencerminkan kode aksi atau tindakan perempuan yang bertentangan dengan ajaran agama maupun adat dan budaya. Seorang istri tidak boleh minta talak selama suaminya menjalani segala kewajiban dan tanggung jawabnya terhadap istrinya. Seorang boleh mengajukan talak apabila suami tidak menjalankan kewajiban dan tugasnya sebagai seorang suami. Allah SWT. memberikan balasan bagi perempuan yang minta talak kepada suaminya, sebagaimana kutipan tersebut yaitu di saat bangkit dari kuburnya badannya berwarna hitam, lidahnya keluar, memiliki ekor yang panjang empat puluh hasta, memiliki dua parji dan bangkitnya bertelanjang.

Berdasarkan gambaran tersebut, seorang istri harus menjaga keharmonisan keluarga dan jangan sampai meminta talak terhadap suaminya tanpa alasan yang mendasar, karena balasan Allah SWT. di akhirat sangat berat. 
LINGUA, Vol. 16, No. 2, September 2019

p ISSN: 1979 9411; e ISSN: 2442 238X

Http://lingua.soloclcs.org; Email: presslingua@gmail.com

Center of Language and Cultural Studies, Surakarta, Indonesia

Kamarudin, Lalu; Syahdan \& Mahyudi, Johan. 2019. Kode Lakuan Perempuan

dalam Naskah Qurtubi Karya TGH. Alimuddin Praya Nusa Tenggara Barat.

Lingua (2019), 16(2): 247-270. Http://doi.org/10.30957/lingua.v16i2.271.

\subsection{Kode Lakuan Perempuan yang Menggambarkan Perilaku Menjaga atau Memelihara}

a. Perempuan yang menyusui anaknya...(hlm : 4).

Kode aksi atau tindakan perempuan yang menyusui anaknya, dalam Islam merupakan tindakan yang wajib. Anak merupakan amanat yang diberikan oleh Allah SWT. yang tiada lengkap, bahkan hambar rasanya kehidupan ini tanpa adanya anak di tengah keluarga kita. Sesungguhnya anak adalah nikmat dan karunia Allah yang mahal harganya. Allah berfirman:

Artinya,"Harta dan anak-anak adalah perhiasan kehidupan dunia, tetapi amalan-amalan yang kekal lagi shaleh adalah lebih baik pahalanya di sisi Tuhanmu serta lebih baik untuk menjadi harapan. "(QS. Al-Kahfi :46).

Orang tua wajib menjaga, memelihara, mengajarinya budi pekerti atau akhlak yang baik terhadap anaknya sebagai bekal yang berguna untuk menghadapi masa depan dan tantangan zaman, sebagaimana sabda Rasulullah SAW. yang artinya :

"Tiada satu pemberian pun dari orng tua terhadap anaknya yang lebih utama dari (mengajarkan ) budi pekerti yang baik," Dalam Riwayat lain, "Seseorang yang mendidik budi pekerti anaknya adalah lebih baik dari sekedar memberi sedekah satu sha",.(HR. At-Turmuzi dan al-Hakim).

TGH.Alimuddin mengambarkan dalam naskah Qurtubi, bahwa tindakan perempuan yang menyusui anaknya juga merupakan kode aksi menjaga dan memelihara. Kode aksi/tindakan perempuan tersebut merupakan aksi/tindakan yang sangat mulia dan berguna terhadap anak untuk masa depannya yang lebih baik. Sehubungan dengan hal tersebut, hendaknya kita memberikan bimbingan, kasih sayang serta pengajaran yang baik.

\section{b. Perempuan yang tiada durhaka pada suaminya..(hlm:56).}

Perempuan yang tidak durhaka atau perempuan yang berbakti kepada suaminya merupakan akhlak atau ciri wanita shalehah. Kode akhlak atau sikap seperti ini perlu dipahami, dijaga dan dipelihara oleh setiap wanita atau istri yang ingin masuk surga, sebagaimana sabda Rasulullah SAW:

Artinya. "Jika seorang istri mengerjakan shalat 5 waktu, berpuasa di bulan Ramadhan, menjaga kemaluannya, menaati suami, niscaya akan dikatakan kepadanya, "masuklah ke surga," (HR. Ahmad) (dalam Afgandi, 2017:59).

TGH. Alimudin menggambarkan melalui dialog Siti Fatimah dengan Rasulullah SAW. sebagai berikut: 
"Maka bertanya Siti Fatimah kepada Ayahandanya Rasulullah SAW., "Ya junjunganku, siapa yang awal-awal perempuan yang masuk di bawah benderaku,". Maka sabda Rasulullah SAW., "Hai anakku Siti Fatimah panggil olehmu tatkala sampai ke kuburnya dan beri olehmu pakaian yang bernama sibaabun sundusi wastabroki akan pakaian perempuan yang tiada durhaka pada suaminya dan suruh masuk di bawah benderamu.."(hlm: 56).

Petikan tersebut, menggambarkan kode akhlak seorang istri yang selalu taat terhadap suaminya, maka ia berada di bawah bendera Siti Fatimah dan ditempatkan di dalam surga bersama-sama orang-orang yang berbuat taat sewaktu di dunia.

\section{c. Perempuan yang suka dipermadu...(hlm:56).}

Sikap atau lakuan bagi perempuan yang suka dipoligami ini menggambarkan sikap yang ikhlas dan rida. Orang yang ihklas dan rida dipoligami oleh suaminya adalah salah satu di antara ciri wanita shaalehah. Wanita shalehah kelak akan mendapatkan ganjaran surga dari Allah SWT. Poligami dalam Islam telah dibatasi oeh aturan atau hukum. Tindakan poligami yang diambil dalam Islam ialah: (1) Membatasi bilangan istri yaitu tidak boleh berkahwin lebih daripada empat, (2) Syarat bagi poligami ialah sanggup menjalankan keadilan di antara istri-istri dan (3) Jika seorang laki-laki khawatir yakni tidak sanggup menjalankan keadilan, hendaknya ia berkahwin dengan seorang saja (Din, 1985 :277). Hukum ini diambil dari Firman Allah SWT:

Artinya: "Kemudian jika kamu bimbang tidak akan berlaku adil (di antara istriistri kamu) maka (berkahwinlah dengan) seorang saja, atau hamba sahaya perempuan yang kamu miliki.”(QS. An-Nisaa' :3).

Di dalam Naskah Qurtubi, TGH. Alimuddin menggambarkan balasan bagi perempuan yang suka dimadu sebagai beriku:

". Maka sabda Rasulullah SAW., "Hai anakku Siti Fatimah panggil olehmu tatkala sampai ke kuburnya dan beri olehmu pakaian yang bernama sibaabun sundusi wastabroki akan pakaian perempuan yang tiada durhaka pada suaminya dan suruh masuk di bawah benderamu dan anak-anak mati kecil sebelum baliq. Kemudian panggil olehmu perempuan yang suka dipermadu/diperduakan,...maka suruh masuk di bawah benderamu supaya jangan dimakan oleh api neraka itu”...(hlm: 56).

Di bagian lain, TGH. Alimuddin menggambarkan balasan perempuan yang tulus ikhlas dan rida sebagaimana kutipan berikut:

"Maka bersabda Rasulullah SAW. kepada anaknya Siti Fatimah dengan sabdanya,"Hai anakku Fatimah, panggil olehmu dua perempuan yang bermadu serta engkau suruhkan berpakaian keduanya.".(hlm: 76). 
Data tersebut mencerminkan balasan bagi perempuan yang ihklas, rida dipoligami oleh suaminya. Dia mendapatkan tempat di bawah bendera Siti Fatimah bersama orang-orang yang baik.Sebaiknya, perempuan-perempuan yang dimadu menjaga, memelihara, berakhlak mulia terhadap suami dan keluarga lainnya, sehingga tercipta keluarga yang sakinah,mawaddah warahmah dan Allah SWT. menjanjikan tempat kembali yang baik yaitu surga.

\section{d. Perempuan yang mati lakinya yang rida..(hlm:56).}

Tindakan atau sikap yang perlu dijaga dan dipelihara oleh perempuan yang ditinggal suaminya adalah sikap rida, sabar dan ikhlas atas kepergian suami. Hakikatnya ujian dan musibah yang menimpa kita adalah tangga bagi kita untuk dapat mencapai derajat yang lebih tinggi di hadapan Allah, jika kita mampu menghadapi segala ujian dan musibah tersebut dengan kesabaran. Sikap sabar, rida dan ikhlas merupakan akhlak yang mulia, sehingga Allah selalu menyertai orang-orang yang sabar dengan berbagai pertolongan, sebagaimana firmanNya:

Artinya: 'Sesungguhnya Allah bersama orang-orang yang sabar.'(QS. AlAnfal:46).

Firman Allah yang lain:

Artinya: " Jadikanlah sabar dan salat sebagai penolongmu. Dan sesungguhnya yang demikian itu sungguh berat,kecuali bagi orang-orang yang khusuk".(QS. Al-Baqarah:45).

Artinya: "Hai orang-orang yang beriman, bersabarlah kamu dan kuatkanlah kesabaranmu dan tetaplah bersiap siaga dan bertaqwalah kepada Allah supaya kamu beruntung." (QS. Ali-Imran:200).

Ayat di atas, mencerminkan sikap sabar dalam menerima berbagai musibah atau ujian dari Allah SWT. yaitu dengan cara meningkatkan ketaqwaan kepada Allah SWT. Orang-orang yang beriman, bersabar dan bertaqwa akan mendapatkan keberuntungan, kebahagiaan, kemuliaan dan tempatnya di surga. TGH. Alimuddin mencerminkan kode lakuan perempuan yang ditinggal mati oleh suaminya, sebagaimana kutipan:

"Maka bertanya Siti Fatimah kepada Ayahandanya Rasulullah SAW., "Ya junjuanganku, siapa yang awal-awal perempuan yang masuk di bawah benderaku,". Maka sabda Rasulullah SAW., "Hai anakku Siti Fatimah panggil olehmu tatkala sampai ke kuburnya dan beri olehmu pakaian yang bernama sibaabun sundusi wastabroki akan pekakas perempuan yang tiada durhaka pada suaminya dan suruh masuk di bawah benderamu dan anak-anak mati kecil sebelum baliq. Kemudian panggil olehmu perempuan yang suka 
LINGUA, Vol. 16, No. 2, September 2019

p ISSN: 1979 9411; e ISSN: 2442 238X

Http://lingua.soloclcs.org; Email: presslingua@gmail.com

Center of Language and Cultural Studies, Surakarta, Indonesia

Kamarudin, Lalu; Syahdan \& Mahyudi, Johan. 2019. Kode Lakuan Perempuan

dalam Naskah Qurtubi Karya TGH. Alimuddin Praya Nusa Tenggara Barat.

Lingua (2019), 16(2): 247-270. Http://doi.org/10.30957/lingua.v16i2.271.

dipermadu/diperduakan, panggil olehmu sekalian perempuan yang mati lakinya yang rida"..(hlm :56).

Kutipan tersebut mencerminkan kode aksi/akhlak perempuan yang patut dijaga dan dipertahankan. Perempuan seperti itulah yang akan mendapatkan naungan di bawah bendera Siti Fatimah di Padang Mahsyar. Dalam kehidupan ini kita sering menjumpai bermacam-macam problem, suka duka, bahagia dan derita, lega hati dan kecewa silih bergandi, sehat dan sakit, senyum dan air mata datang dan pergi. Semua itu menuntut kesabaran, kekuatan iman dan mental, sebab tanpa kekuatan itu kita akan terombangambing oleh tipu daya setan.

\section{e. Perempuan yang baik...(hlm:68).}

Aksi perempuan yang selalu berbuat baik dan berakhlak mulia merupakan ciri wanita shalihah yang patut dijaga dan dipelihara oleh setiap wanita. Perempuan yang taat ini akan mendapat tempat yang istimewa yaitu surga. Di dalam naskah Qurtubi tersebut, TGH. Alimuddin menggambarkan balasan bagi perempuan yang selalu berbuat baik, taat kepada Allah dan RasulNya, sebagaimana kutipan berikut:

"Kemudian datanglah kanak-kanak itu pada kubur ibunya, serta berkata-kata ia,"Amin yaa Rasulullah," dan bersaf-ssaflah sekalian di atas kubur ibunya, karena menghormatkan akan ibunya. Maka katanya kanak-kanak itu dengan katanya," Hai ibuku bangunlah engkau pada ini hari dan inilah buah matamu yang belum sempurna pemeliharaanmu di dalam dunia, sekarang telah bersafsaflah kami menanti akan dikau," maka mendengarlah ibunya akan panggilan anaknya seperti serasa di dalam dunia jua. Maka terkejutlah ibunya lalu bangun daripada kuburnya, maka tiba-tiba mendapat anaknya seperti rupa di dalam dunia jua. Maka tahu akan anaknya serta berkata-kata pada anaknya dengan katanya, "dimana tempat bapakmu, sudahkah engkau berjumpa dengan dia". Maka sahut anaknya,"Bapakku telah duduk di bawah Areys Arrahman," maka terdengar oleh Siti Fatimah perkataan kanak-kanak itu, maka kata Siti Fatimah pada ibu kanak-kanak dengan katanya, "marilah engkau masuk di bawah benderaku supaya selasai janjiku dengan engkau dan inilah pekakas dan mahkota serta burokmu," maka masuklah di bawah bendera Siti Fatimah dengan sekalian anaknya, maka menyuruhkan, memakaikan dan menunggangkan buroknya dan diiringkan oleh sekalian anaknya, maka sukalah dengan sehabis-habis suka...(hlm: 68).

Kutipan tersebut merupakan cerminan kode aksi/tindakan perempuan yang selalu berbuat baik yaitu berada di bawah naungan bendera Siti Fatimah di Padang Mahsyar bersama anaknya, diberikan mahkota dan burok sebagai kendaraannya dan pasti mendapatkan tempat di surga bersama Siti Fatimah dan orang-orang yang selalu berbuat taat keada Allah dan RasulNya. 
LINGUA, Vol. 16, No. 2, September 2019

p ISSN: 1979 9411; e ISSN: 2442 238X

Http://lingua.soloclcs.org; Email: presslingua@gmail.com

Center of Language and Cultural Studies, Surakarta, Indonesia

Kamarudin, Lalu; Syahdan \& Mahyudi, Johan. 2019. Kode Lakuan Perempuan

dalam Naskah Qurtubi Karya TGH. Alimuddin Praya Nusa Tenggara Barat.

Lingua (2019), 16(2): 247-270. Http://doi.org/10.30957/lingua.v16i2.271.

\section{f. Sembah perempuan yang nusyus itu...(hlm :72).}

Perempuan yang nusyus itu menyampaikan rasa hormatnya kepada Rasulullah SAW. dengan mengajukan pertanyaan tentang mengapa dia mendapatkan siksa seberat itu, tentang apa salahnya, sementara di dunia dia selalu menjalakan shalat, puasa, berzakat dan berhaji. Maka dijawab oleh Rasulullah bahwa yang tahu salahnya adalah dirinya sendiri, sebagaimana kutipan beriku:

"Maka sembah perempuan yang durhaka itu pada Rasulullah dengan katanya,"Yaa Rasulullah, apa salah hamba ini ?, karena di dalam dunia mengerjakan sembahyang dan puasa dan berzakat dan haji". Maka bersabda Rasulullah SAW. pada perempuan itu, dengan sabdanya, "Hai umatku tiada aku tahu salahmu, melainkan kamu sendiri, karena jadi saksi anggotamu"...(hlm:72).

TGH. Alimuddin menggambarkan kode aksi perempuan yang nusyuz itu terhadap Rasulullah SAW. perempuan itu tetap menaruh rasa hormatnya kepada Rasulullah, walaupun dia dalam keadaan sakit karena siksa yang diterimanya. Aksi hormatnya perempuan tersebut, terhadap Rasulullah SAW. merupakan sikap yang patut dijaga dan dipelihara oleh siapa pun yang mengaku dirinya sebagai umat nabi Muhammad SAW. dan sebagai orang yang beriman.

\section{g. Berpakaian sekalian perempuan...(hlm:79).}

Aksi perempuan yang mengenakan pakainnya tergambar dalam kutipan berikut:

"Kemudian menyuruh Siti Fatimah kepada sekalian perempuan yang di bawah Areys itu dengan katanya,"Hai sekalian perempuan yang berada di bawah Areys berpakaian olehmu dan tunggang olehmu burokmu". Kemudian berpakaian sekalian perempuan itu dan buroknya sudah bersedia dan berbarisbarislah sekalian perempuan itu, karena menunggu Siti Fatimah ....(hlm :79).

Kutipan ini, mencerminkan kode aksi perempuan yang memakai pakaiannya yang telah disediakan. Mereka mengenakan pakaian atas perintah Siti Fatimah, karena mereka akan pergi ke Padang Mahsyar. Aksi perempuan ini merupakan aksi balasan atas perbuatan kebajikan sewaktu di dunia. Oleh karena itu, seorang perempuan harus menjaga dan memelihara kewajiban dan memelihara dirinya yaitu menutup aurat dengan menggunakan pakaian yang baik.

\section{SIMPULAN}

Berdasarkan penyajian dan pembahasan yang dikemukakan di atas, dapat disimpulkan bahwa kode lakuan atau aksi perempuan yang tergambar dalam naskah Qurtubi terdiri dari 15 kode lakuan yang menggambarkan lakuan kebaikan sosial yaitu: 1) Perempuan yang menyusui, 2) Bangunlah Siti Fatimah dari kuburnya, 3) Memandang Siti Fatimah ke kanan-ke kiri, 4) Pergilah Siti Fatimah menghadap Rasulullah SAW., 5) 
LINGUA, Vol. 16, No. 2, September 2019

p ISSN: 1979 9411; e ISSN: 2442 238X

Http://lingua.soloclcs.org; Email: presslingua@gmail.com

Center of Language and Cultural Studies, Surakarta, Indonesia

Kamarudin, Lalu; Syahdan \& Mahyudi, Johan. 2019. Kode Lakuan Perempuan

dalam Naskah Qurtubi Karya TGH. Alimuddin Praya Nusa Tenggara Barat.

Lingua (2019), 16(2): 247-270. Http://doi.org/10.30957/lingua.v16i2.271.

Menunggang burok Siti Fatimah, 6) Datang Siti Fatimah ke hadapan Rasulullah SAW., 7) Menyahut Siti Fatimah, 8) Melihat Siti Fatimah laki-laki perempuan yang belum bangun itu, 9) Bertanya Siti Fatimah kepada Rasulullah, 10) Perempuan yang tiada durhaka pada suaminya, 11) perempuan yang suka dipermadu, 12) perempuan yang mati atau meninggal lakinya yang rida, 13) perempuan yang bakti kepada dua ibu bapaknya,14) Perempuan yang tidak pernah berkahwin di dunia yang rida, 15) Menyahutlah perempuan yang bakti pada lakinya.

Tujuh kode lakuan perempuan yang mengambarkan pertentangan ialah: 1) Perempuan yang durhaka pada suaminya, 2) Perempuan yang durhaka kepada kedua orang tuanya, 3) Perempuan yang tiada suka diperduakan atau dipoligami, 4) Malu perempuan yang durhaka itu, 5) Berteriaklah sekalian perempuan yang durhaka itu, 6) Perempuan yang nusyuz pada lakinya, 7) Perempua yang minta talak pada lakinya.

Sebelas kode lakuan perempuan yang menggambarkan sikap menjaga atau memelihara yaitu: 1) Perempuan yang menyusui anaknya, 2) Menghadap Siti Fatimah ke Rasulullah SAW, 3) Menyahut Siti Fatimah, 4) Bertanya Siti Fatimah pada Ayahnya, 5) Perempuan yang tiada durhaka pada suaminya, 6) Perempuan yang suka dipermadu, 7) Perempuan yang mati lakinya yang rida, 8) Perempuan yang tidak pernah berkahwin yang rida, 9) Perempuan yang baik, 10) Sembah perempuan yang nusyus itu, 11) Berpakaian sekalian perempuan itu.

Di dalam kehidupan akhirat, manusia akan dimintai pertanggungjawaban atas segala aksi atau perbuatan yang telah dilakoni di dunia. Allah memberikan ganjaran atau balasan sesuai amal ibadah seseorang. Bila amal kebaikan seseorang lebih banyak dari keburukannya, maka orang tersebut mendapatkan tempat di surga. Sebaliknya, bila amal kejelekan seseorang lebih banyak, maka orang tersebut akan ditempatkan di neraka dengan berbagai siksa.

\section{DAFTAR PUSTAKA}

Abidin, Munirul. 2011.Paradigma Tafsir Perempuan di Indonesia. Malang. UIN-Maliki Press.

Afgandi, Iis Nur'aini. 2017. Ternyata Wanita Lebih Mudah Masuk Surga. Jakarta Selatan: PT. Kawan Pustaka.

Aizid, Rizem. 2015. Ketika Ruh Dikembalikan. Yogyakarta: Saufa.

Arikunto, Suharsimi. 2010. Prosedur Penelitian Suatu Pendekatan Praktik.Jakarta: PT.Rineka Cipta.

Atmosuwita, Subijantoro. 2010. Perihal Sastra dan Religiusitas Dalam Sastra.

Bandung : Sinar Baru Algensindo.

Bahreisy, Hussein. 1980. Himpunan Hadits Pilihan Hadits Shahih Buhari. Surabaya: Al-Ikhlas.

Barthes, Roland. 2007. Petualangan Semiologi. Yogyakarta : Pustaka Pelajar.

Barthes.Roland. 1985. L'Aventure Semiologique. Paris : Editions du Seuil.

Barthes, Roland. 2010. Membedah Mitos-Mitos Budaya Semiotika atau Sosiologi

Tanda, Simbol, dan Representasi.Yogyakarta : Jalasutra. 
LINGUA, Vol. 16, No. 2, September 2019

p ISSN: 1979 9411; e ISSN: 2442 238X

Http://lingua.soloclcs.org; Email: presslingua@gmail.com

Center of Language and Cultural Studies, Surakarta, Indonesia

Kamarudin, Lalu; Syahdan \& Mahyudi, Johan. 2019. Kode Lakuan Perempuan dalam Naskah Qurtubi Karya TGH. Alimuddin Praya Nusa Tenggara Barat. Lingua (2019), 16(2): 247-270. Http://doi.org/10.30957/lingua.v16i2.271.

Beroroh, Baried. 1985. Memahami Hikayat Dalam Sastra Indonesia. Jakarta : Pusat Pembinaan dan Pengembangan Bahasa Departemen Pendidikan dan Kebudayaan.

Chulsum, Umidan Novia Windi. 2006. Kamus Besar Bahasa Indonesia. Surabaya : Kashiko.

Eco, Umberto. 2005. Trori Semiotik Terjemahan. Yogyakarta : Kreasi Wacana.

Emzir dan Rohman, Saefur. 2014. Teori dan Pengajaran Sastra. Jakarta : PT.Raja Grafindo Persada.

Fakih, Mansour. 2005. Analisis Gender dan Tranformasi Sosial. Yogyakarta: Pustakan Pelajar.

Fathurrahman ,Oman. 2015. Filologi Indonesia Teori dan Metode. Jakarta :Prenadamedia Grup.

Hasyim, Syatiq. 2005. Pengantar Feminisme dan Fundamentalisme Islam. Yogyakarta: LKIS.

Herman,J.v. dan Suparman,Gde. 1990. Bunga Rampai Kutipan Naskah Lama dan Aspek Pengetahuannya. NTB :Departemen Pendidikan dan Kebudayaan.

Hidayatulloh, Agus., dkk. 2013. Alwasim, Al-Qur'an Tajwid Kode, Transliterasi Per Kata, Terjemah Per Kata. Kota Bekasi: Cipta Bagus Segara.

Humam, As'Ad. 1995. 100 Hadits terjemahan. Yogyakarta : Team Tadarus 'AMM'

Khair, Raisa Ummul. 2017. Istri Yang Selamat dari Siksa Kubur, Ganjaaran dalam Kubur Bagi Istri Yang Memuliakan Suami. Yogyakarta : Saufa.

Lustyantie, Ninuk. 2012. Pendekatan Semiotika Roland Barthes. Artikel disampaikan pada seminar Nasional FIB UI, 19 Desember 2012.

Muthahari, Murtadlo. 1995. Hak-hak Wanita dalam Islam. Jakarta: Lentera.

Moleong, Lexy J. 2011. Metodologi Penelitian Kualitatif.Bandung: PT.Remaja Rosdakarya.

Vera, Nawiron. 2014. Semiotika dalam Riset Komunikasi. Bogor :Ghalia Indonesia. 
LINGUA, Vol. 16, No. 2, September 2019

p ISSN: 1979 9411; e ISSN: 2442 238X

Http://lingua.soloclcs.org; Email: presslingua@gmail.com

Center of Language and Cultural Studies, Surakarta, Indonesia

Kamarudin, Lalu; Syahdan \& Mahyudi, Johan. 2019. Kode Lakuan Perempuan

dalam Naskah Qurtubi Karya TGH. Alimuddin Praya Nusa Tenggara Barat.

Lingua (2019), 16(2): 247-270. Http://doi.org/10.30957/lingua.v16i2.271. 